\title{
RELATIONSHIP BETWEEN ARTEMIA POPULATION DYNAMICS AND CHLOROPHYLL A FLUCTUATIONS IN URMIA LAKE (IRAN)
}

\author{
DAHESHT, L.E. ${ }^{1 *}$; MUSTAFAYEV, Q. ${ }^{2}$; MOHEBBI, F. ${ }^{1} \&$ AHMADI, R. ${ }^{1}$ \\ 1 - Iranian Artemia Research Center, Iran. \\ 2 - Faculty of Biology, Baku State University, Azerbaijan. \\ *Corresponding author: latifsmaili@gmail.com
}

\begin{abstract}
Dahesht, L.E.; Mustafayev, Q.; Mohebbi, F. \& Ahmadi, R. 2013. Braz. J. Aquat. Sci. Technol. 17(2):1-6. elSSN 19839057. DOI: 10.14210/bjast.v17.n2.p1-6. Determination of chlorophyll $a$ is one of the most common methods for measuring the primary production in the lakes and sea water. We studied Artemia Leach. dynamics and chlorophyll a fluctuation and their relationship in Urmia Lake. Sampling was performed monthly during one year (2007) at eleven sampling stations in Urmia Lake. Population dynamics analysis of Artemia from Urmia Lake suggested that the highest diversity in various Artemia morphological stages was present from May to July and the highest densities in March. On the other hand, no morphological stages were observed, at all stations in the lake, from January to April. The mean chlorophyll a concentration in Urmia Lake was $0.8 \mu \mathrm{g} . \mathrm{L}^{-1}$, and the highest and the lowest concentrations of chlorophyll a were measured in June and July with $2.53 \mu \mathrm{g} . \mathrm{L}^{-1}$ and $0.1 \mu \mathrm{g} . \mathrm{L}^{-1}$ respectively. According to the Carlson classification Urmia Lake was oligothrophic. Artemia biomass appeared in the mid spring and bloomed in the summer. Generally, there was a negative relationship between Artemia population and chlorophyll a.
\end{abstract}

Key words: Artemia, hypersaline lake, primary production, phytoplankton,

\section{INTRODUCTION}

Urmia lake is a thalasohaline lake and one of the most hypersaline lakes in the world (Abbaspour \& Nazaridoust, 2007). It is located at $37^{\circ} 30^{\prime} \mathrm{N}$ and $45^{\circ} 30^{\prime} \mathrm{E}$, with a surface area of 4750 to $6100 \mathrm{Km}^{2}$ and mean depth of $6.0 \mathrm{~m}$ (Eimanifar \& Mohebbi, 2007). This lake is $130-150 \mathrm{~km}$ long and $20-50 \mathrm{~km}$ wide, being located at $1280 \mathrm{~m}$ above sea level (Karimi \& Rankuhi, 2007). The salinity of the lake has risen from 175 to 340 ppt during last decade (Negarestan, 2001, 2004). Lake Urmia requires annually $3086 \mathrm{MCM}$ of inflow water to maintain a sustainable ecosystem(Abbaspour \& Nazaridoust, 2007). Urmia Lake is a hypersaline

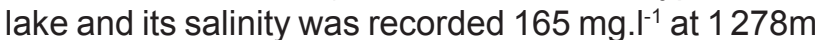
above sea level in 1995 (Sorgeloos, 1997). Since 1997, the water volume of the lake has begun to decrease. Similarly, the area of the lake has been decreased approximately $1040 \mathrm{~km}^{2}$ from August 1998 to August 2001. This result has been verified through TOPEX/ Posidon satellite information that indicated a variation of three meters in water depth (Alesheikh et al., 2004). The water level has decreased about $23 \%$ during the last decade. Such large changes around Urmia Lake coastline occurred due to a 3 to 4 meters decrease in water depth (Rasuly, 2006).

Zooplankton species diversity is severely reduced in hypersaline $(>50 \mathrm{~g} / \mathrm{kg}$ ) lakes compared to less saline and fresh water lakes (Jelison \& Melack, 2001). In this regard, Urmia Lake as a hypersaline lake has an extremely simple food chain. This makes it a very sensitive ecosystem (Abbaspour \& Nazaridoust, 2007).
This lake is similar to the Great Salt Lake in some characteristics such as area, salinity and Artemia presence. Similarly, the food chain in the Great Salt Lake system is relatively simple. For birds, food sources available directly from the lake are restricted to Artemia, Artemia cysts, brine flies and its larvae (Johnson et al., 2005).

One of the largest hypersaline lakes in the USA is Mono Lake in California that contains Artemia but its salinity differs from that of Urmia Lake. Its salinity ranged from 48 to $93 \mathrm{~g} / \mathrm{l}$ between 1941 and 1982 (Dana \& Lenz, 1986). The lake has a simple food web, with the brine shrimp Artemia as the main zooplankton (Jiang et al., 2004). Mason (1967) noted the presence of several species of protozoan; two rotifers and the endemic Artemia monica Verrill.

Although Artemia Leach. has been known for centuries, its use as a food for larviculture began in 1930's. The lake's Artemia, that are affected by algae, are crucial from fisheries point of view (Sorgeloos et al., 1998; Mohebbi et al., 2006).

The economic harvesting of Artemia urmiana from Urmia Lake began in Iran in 1996. Urmia Lake is one of the largest permanent hypersaline lakes in the world, a unique habitat including bisexual $A$. urmiana (Azari Takami, 1987; Esmaili, 2005; Eimanifar \& Mohebbi, 2007). Artemia is mainly fed with phytoplankton and detritus.

In lakes, plankton plays a key role in nutrient cycling (Mackenzie et al., 2001). Phytoplankton play an important role in maintaining the global carbon cycle (Mitra et al., 2004) and are considered as the main primary producers in water ecosystems. Chlorophyll a 
is present in all phytoplankton groups and its measurement is a well-known method for the determination of primary production in aquatic ecosystems (Winder \& Cloern, 2010). The purpose of this paper was to study the Artemia dynamics and chlorophyll a fluctuation and their relationship in Urmia Lake.

\section{MATERIALS AND METHODS}

Urmia Lake has been divided into north and south arms by a causeway which was built on the lake. To facilitate water flow between the north and south part of the lake, there is a $1400 \mathrm{~m}$ narrow area (Van Stappen et al., 2001) that has recently been covered by a bridge. In this study, 11 sampling sites (A, B, C, $D, E, F, G, H, K, M$ and $N$ ) were selected in the middle, northern, and southern parts of Urmia Lake (Fig. 1). Sampling was performed monthly during 2007.

Samples for chlorophyll a determination were taken at $0.5 \mathrm{~m}$ depth and filtered through a glass fiber filter (GF/C) buffered with magnesium carbonate. Phytoplankton chlorophyll a concentrations were estimated according to standard methods (Parsons \& Strickland, 1965) after $24 \mathrm{~h}$ extraction in $90 \%$ cold acetone.

It is considered that like other zooplanktons, Artemia distribution is heterogeneous and its different stages are transported to various regions of the lake by water flows (Stephens \& Birdsey, 2002). Therefore, we selected a stratified random design for Artemia sampling. Artemia sampling was performed either along a transect by towing a $100 \mu$ mesh net on the surface $(20 \mathrm{~cm})$ or by pumping water from $2.5 \mathrm{~m}$ depth. Artemia population composition and abundance were determined using an Olympus VMZ 1X-4X stereomicroscope. Its wet and dry weights were measured by a Sartorius BA110F digital balance after $24 \mathrm{~h}$ at $60^{\circ} \mathrm{C}$ (Lavens \& Sorgeloos, 1997).

All data including chlorophyll $a$, the number of Artemia morphological structures and Artemia biomass (wet weight) were analyzed using one-way analysis of variance (ANOVA) followed by Fisher LSD test after performing homogeneity test with SPSS software.

\section{RESULTS}

The density of Artemia in various morphological stages and of cysts are shown in figures 2 and 3 respectively. Analysis of population dynamics of Artemia from Urmia Lake showed that the maximum mean of different morphological structures of Artemia such as 'nauplii + meta nauplii', juvenile, adult males and adult females, were $565 \pm 84$ ind. $\mathrm{m}^{-3}$ in May; $6.7 \pm 3.2$ ind. $\mathrm{m}^{-3}$ in May; $187.8 \pm 6.8$ ind $\mathrm{m}^{-3}$ in July and $146.7 \pm 35.1$ ind. $\mathrm{m}^{-3}$ in June respectively. Similarly, reproductive females (with cysts bearing ovisacs) had a density of $70 \pm 23$.8ind. $\mathrm{m}^{-3}$ in July. On the other hand, mean maximum cysts density in the lake water was $81.7 \pm 24$ ind. $\mathrm{L}^{-1}$ which was observed in March. The minimum mean values for all morphological structures were 0ind. $\mathrm{m}^{-3}$ from January to April, when the lake was void of any live Artemia. This value for cysts was $82.5 \pm 0.8 \mathrm{ind} . \mathrm{L}^{-1}$. The absolute maximum density of 'nauplii + meta nauplii', juvenile, adult males and adult females and reproductive fe-

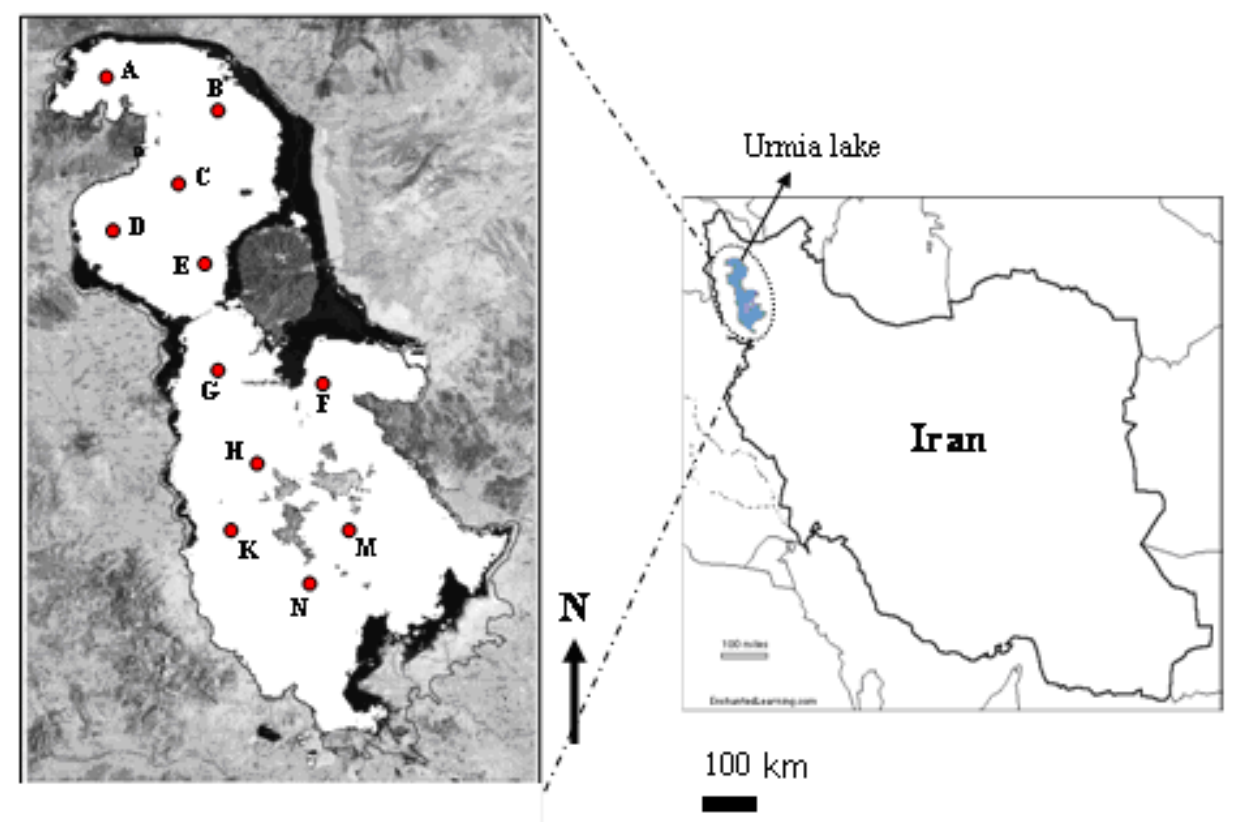

Figure 1 - Sampling sites location in Urmia Lake. 
males observed in this study were $28.9 \pm 19.1$ ind $\mathrm{m}^{-3}$ in site $\mathrm{G} ; 4.1 \pm 3$.0ind. $\mathrm{m}^{-3}$ in site $\mathrm{G} ; 86.7 \pm 25.6$ ind $\mathrm{m}^{-3}$ in site $\mathrm{N} ; 52.3 \pm 14.9$ ind. $\mathrm{m}^{-3}$ in site $\mathrm{N}$ and $73.4 \pm 26.5$ ind. $\mathrm{m}^{-3}$ in site $\mathrm{H}$, respectively. Also, the highest cysts density was 127.3 \pm 36 .3ind. $\mathrm{L}^{-1}$ was observed in site B. Furthermore, the absolute and the mean maximum wet weights of Artemia biomass appeared in site $\mathrm{N}$ with $4.4 \pm 2.3 \mathrm{mg} . \mathrm{L}^{-1}$ and $3.1 \pm 1.7 \mathrm{mg} . \mathrm{L}^{-1}$ respectively which was observed in June (fig. 4).

The monthly fluctuation of chlorophyll a during the study period is shown in figure 4 . The maximum and minimum mean of chlorophyll a was obtained $2.4 \pm 0.2 \mu \mathrm{g} . \mathrm{L}^{-1}$ and $0.46 \pm 0.2 \mu \mathrm{g} . \mathrm{L}^{-1}$ in June and November respectively. The highest and lowest concentration of chlorophyll a were found in sites $E$ and $\mathrm{G}$ with $1.0 \pm 0.7 \mu \mathrm{g} \cdot \mathrm{L}^{-1}$ and in site $\mathrm{H}$ with $0.1 \pm 0.2 \mu \mathrm{g} \cdot \mathrm{L}^{-1}$, respectively. According to data analysis by One-way ANOVA, chlorophyll a concentration and Artemia biomass and densities were negatively related to each other and statistically were significant $(P<0.05)$ during the study period.

\section{DISCUSSION}

As mentioned earlier, Artemia habitats are extreme, old and hold a unique and simple biodiversity composition (Gajardo et al., 2006). Since, there are no recorded salinities lower than 140 ppt in Urmia Lake, no other zooplankton except Artemia has been reported there.

Due to its high salinities, only few species of phytoplankton can resist such an environment like Urmia Lake. Quantitative analysis of phytoplankton density indicated that primary production in Urmia Lake was lower than that of the Great Salt Lake (Gliwicz et al., 1995).

The best known halotolerant or halophilic eukaryotic algae are species of genus Dunaliella (Javor, 1989). Dunaliella was found in the highest salinity ranges i.e., 99 to 145ppt (Melack et al., 1999). This green algae was the dominant phytoplankton of Urmia Lake (Shoahassani, 1996; Mohebbi et al., 2006) there-

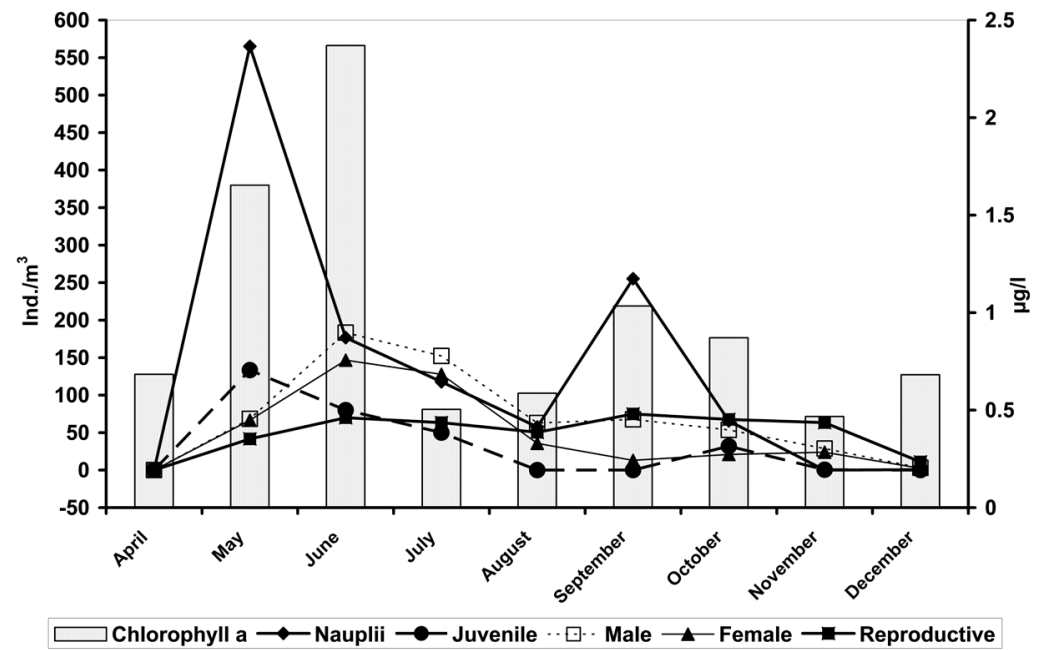

Figure 2 - Fluctuations of Artemia in various morphological stages and chlorophyll a in Urmia Lake.

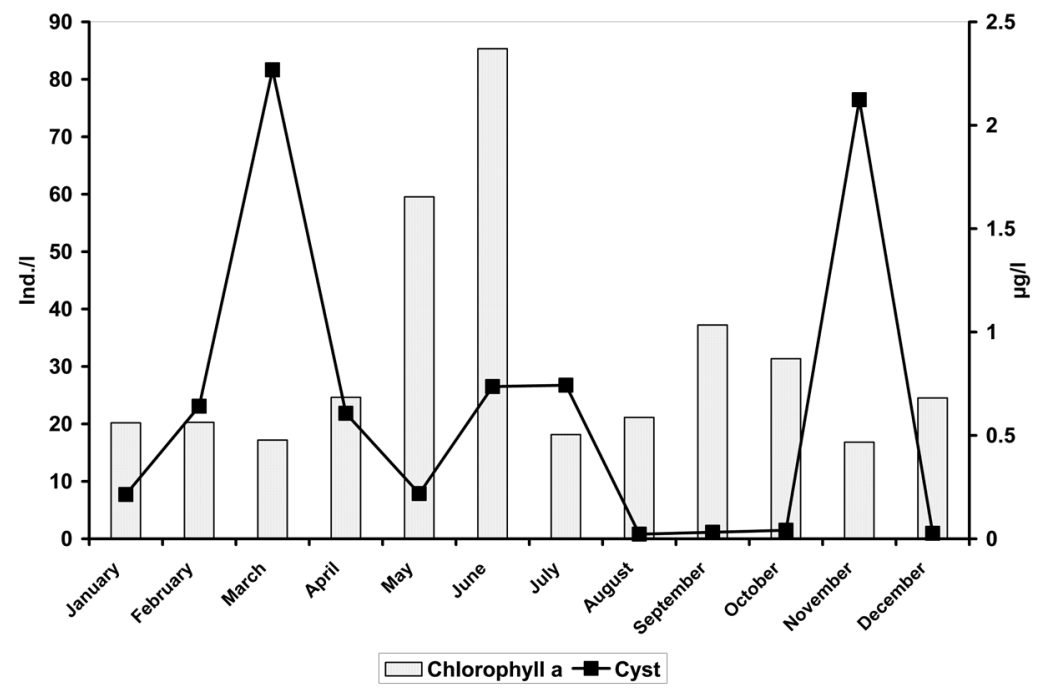

Figure 3 - Fluctuations of Artemia cysts and chlorophyll a in Urmia Lake. 


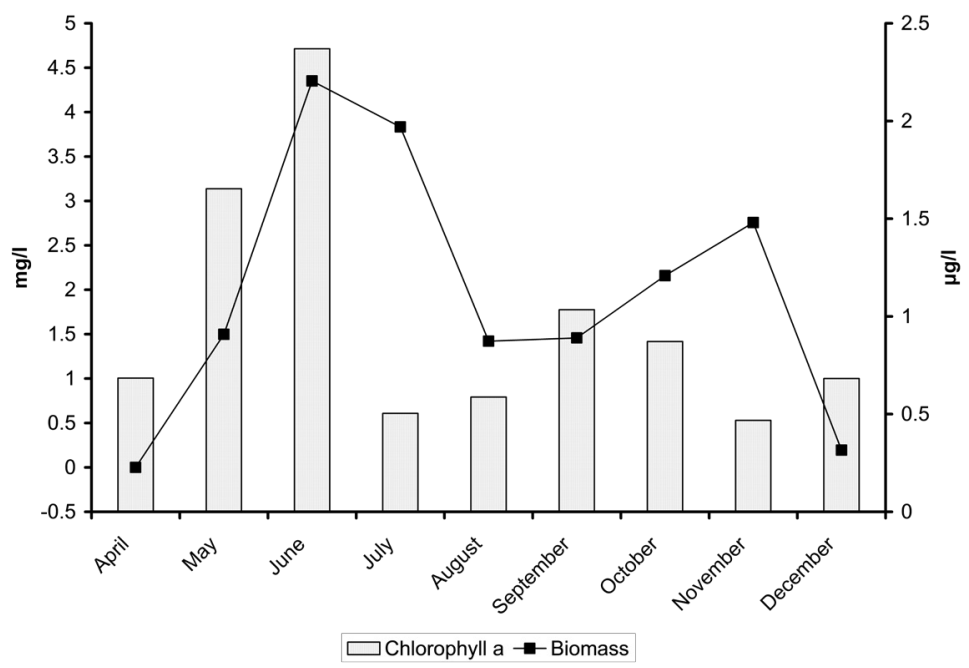

Figure 4. Monthly fluctuations of chlorophyll a and Artemia biomass in Urmia Lake.

fore being the main contributor to the chlorophyll a concentration in this lake.

In winter, when temperature was below $3^{\circ} \mathrm{C}$ in the Great Salt Lake, Artemia were completely absent from the lake, phytoplankton abundance was high $(\geq 13$ $\mathrm{Chl}$ a $\left.\mu \mathrm{g} \cdot \mathrm{L}^{-1}\right)$ and the dominant grazers were ciliated protozoans (Wurtsbaugh \& Gliwicz, 2001). A similar scenario was observed in Urmia Lake but with lower phytoplankton densities. In this lake, chlorophyll a values ranged from 0 to $4.71 \mu \mathrm{g} \cdot \mathrm{L}^{-1}$. Average monthly values, however, seldom exceeded $1 \mu \mathrm{g} . \mathrm{L}^{-1}$ and chlorophyll a levels reached a maximum in NovemberDecember (Van Stappen et al., 2001). In the present study, the highest and the lowest values of chlorophyll a in Urmia Lake were $2.37 \pm 1.35 \mu \mathrm{g} . \mathrm{L}^{-1}$ and $0.46 \pm 0.2 \mu \mathrm{g} . \mathrm{L}^{-1}$ in late spring and late autumn respectively. Generally, in this study, the average value of chlorophyll $a$ in Urmia Lake was $0.8 \pm 0.3 \mu \mathrm{g} . \mathrm{L}^{-1}$. Therefore, with regard to chlorophyll a concentration and according to Carlson (1996) classification, we may attribute Urmia Lake as oligothrophic.

Two peaks were observed in the chlorophyll a concentration: a higher one occurred in late spring (June) and a lower one in October, which coincided with Artemia densities fluctuations observed in this study. The highest and the lowest densities of Artemia cysts were $324 \pm 81.7$ ind. $\mathrm{L}^{-1}$ and $4.5 \pm 0.8 \mathrm{ind} . \mathrm{L}^{-1}$ in late winter and mid summer, respectively. Artemia biomass appeared in mid spring and bloomed in summer, when it reached $4.4 \pm 3.3 \mathrm{mg} . \mathrm{L}^{-1}$ (fig.4). As the temperature rose in May, the nauplii density increased to its highest value (565ind $\mathrm{m}^{-3}$ ) then, it completely disappeared in December. No nauplii were observed in early spring. In general, there were no morphological stages of Artemia observed during winter. Few juvenile could be observed because of the relatively rapid development of Artemia (nauplii to adults). The high densities of juveniles were observed in May when nauplii had also high densities.

In 2001, the average temperature of Urmia Lake water surface layers was reported as $27.2^{\circ} \mathrm{C}$ in summer, $9.1^{\circ} \mathrm{C}$ in autumn and $5.2^{\circ} \mathrm{C}$ in winter (Pourasghar, 2004). Therefore, probably the water temperature plays a crucial role in phytoplankton and Artemia urmiana populations and densities fluctuations. We observed a cyst density peak in November, when there was pratically no Artemia biomass, only cysts. It is not clear why there were few cysts in December and January. Probably they had sunk to the bottom, and therefore not available for the sampling strategy used in this study. Furthermore, more Artemia cysts were observed in late winter and early spring, when compared to other seasons over the lake.

In hypersaline lakes, the development of Artemia is mainly related to two factors: quantity of phytoplankton population and water temperature. Therefore, in the cold season, Artemia biomass decreased and phytoplankton density increased, and therefore so did the chlorophyll a concentration. The changes observed can be described as follows: in winter when temperatures were lower than $2^{\circ} \mathrm{C}$ Artemia were absent from the lake and phytoplankton abundance was relatively low ( 0.7 chl a $\left.\mu \mathrm{g} \cdot \mathrm{L}^{-1}\right)$. In the spring cysts hatched when phytoplankton was abundant $\left(1.7 \mathrm{chl} \mathrm{a} \mu \mathrm{g} . \mathrm{L}^{-1}\right)$ and Artemia grew and produced large egg batches. Despite the high production of nauplii, Artemia densities declined by July and the growing shrimp population grazed down the phytoplankton resource to $0.5 \mathrm{chl} \mathrm{a} \mu \mathrm{g} . \mathrm{L}^{-1}$. In spite of higher phytoplankton food resource during the summer there was limited production of eggs and limited recruitment of juveniles, probably due to the low food availability. 


\section{CONCLUSION}

In Urmia Lake, chlorophyll a concentration and Artemia density were related to each other in such way that phytoplankton production was reduced during the winter due to low temperatures and Artemia density dropped dramatically too. However, primary production increased in warmer months in spite of Artemia presence. This pattern is a natural way by which Artemia preserves its valuable genetic resources in cysts during unfavorable conditions.

\section{REFERENCES}

Abbaspour, M. \& Nazaridoust, A. 2007. Determination of environmental water requirements of Lake Urmia, Iran: An ecological approach. International J. Environ. Stud. 64(2): 161-169.

Alesheikh, A. ; Ghorbanali, A. \& Talebzadeh, A.; 2004. Generation the coastline change map for Urmia Lake by TM and ETM+ imagery. Map Asia conference, Bejing, China.

Azari takami, G. 1987. The use of Artemia from Urmia Lake (Iran) as food for sturgeon. In: Sorgeloos, P.; Bengston, D. A.; Decleir, W. \& Jaspers, E. (eds), Artemia Research and its Application, Vol. 3. Ecology, Culturing, Use in Aquaculture: 467- 468. Belgium: Universa press.

Carlson, R. E. \& Simpson, J. 1996. A coordinator's guide to volunteer lake monitoring methods. North American Lake Management Society.

Dana, G. L. \& Lenz, P.H. 1986. Effects of increasing salinity on an Artemia population from Mono Lake. California, Oecologia, 68: 428-436.

Eimanifar, A. \& Mohebbi, F. 2007. Urmia Lake (Northwest Iran): A brief review. Saline Systems, 3: 5 .

Esmaeili, D. L. 2007. A study on ecosystem of Urmia Lake. MSc. Thesis. Baku: Baku State University.

Gajardo, G. M.; Sorgeloos, P. \& Beardmore, J. A. 2006. Inland hypersaline lakes and the brine shrimp Artemia as simple models for biodiversity analysis at the population level. Saline Syst. 2: 14.

Gliwicz, Z. M.; Wurtsbaugh, W. A. \& Ward, A.; 1995. Brine shrimp ecology in the Great Salt Lake, Utah, performance report to the Utah division of Wildlife Resources. Salt Lake City, Utah.

Javor, B. 1989. Hypersaline environments. Berlin: Springer-verlag.

Jelison, R. \& Melack, J. M. 2001. Nitrogen limitation and particulate elemental ratios of seston in hypersaline Mono Lake, California, USA. Hydrobiologia, 466: $1-12$.
Jiang, S.; Steward, G.; Jellison, R.; Chu, W. \& Choi, S.; 2004. Abundance, distribution and diversity of viruses in alkaline, hypersaline Mono Lake, California. Microb. Ecol. 47(1): 9-17.

Johnson, P. W.; Conover, M.; Wurtsbaugh, W. \& Adams, J.; 2005. Conceptual model for selenium cycling in the Great Salt Lake. USA: Utah Department Of Environmental Quality.

Karimi, M. B.\& Rankuhi, M. R. 2007. A guide of Iranian wetlands that records in Ramsar convention (Convention on wetlands of International, 1971). Iran: Iranian Environmental Conservation Organization press.

Mackenzie, A.; Ball, S. A. \& Virdee, S. R. 2001. Ecology. Oxford: Bios Scientific Publishers Limited.

Mason, D. T. 1967. Limnology of Mono Lake. California: Univ. Calif Pub. Zool.

Melack, J.; Jellison, R. \& Herbst, D. 1999. Saline Lakes. 7th International conference on salt Lakes, held in Death Valley national park. California, Kluwer Academic Publisher.

Mitra, A.; Banerjee, K. \& Gangopadhyay, A. 2004. Introduction to marine plankton. Delhi, Daya Publishing House.

Mohebbi, F.; Asadpour, Y.; Esmaili, L. \& Javan, S. 2006. Phytoplankton population dynamics in Urmia Lake. 14th National and 2nd International conference of biology, Iran, Tarbiat Modarres University.

Negarestan, H. 2001. Stock assessment of Urmia Lake Artemia. Iran, Iranian Fisheries Research Organization, 30p.

Negarestan, H. 2004. Stock assessment of Artemia in Urmia Lake. Iran, 5th International Workshop on Artemia,

Parsons, T. R. \& Strickland, J. D. H. 1965. Particulate organic matter III. I. Pigment analysis. III. I. I. Determination of phytoplankton pigments. J. Fish. Res. Bd. Can. 8: 117-127.

Pourasghar, F. 2004. Study of temperature distribution on Urmia Lake by satellite images. MSc. Thesis. Tehran: Tarbiat Modarres University. 91p.

Rasuly, A. A. 2006. Modelling of Urmia Lake coastal changes by applying an integrated RS/GIS. Approach. Coast GIS Conference Proceedings. Australia.

Shoahasani, A. 1996. The effect of Artemia feeding on the Urmia Lake phytoplankton population. MSc. Thesis. Lahijan: Islamic Azad University of Lahijan.152p.

Sorgeloos, P.; Coutteau, P.; Dhert, P.; Merchie, G. \& Lavens, P.; 1998. Use of brine shrimp, Artemia spp., in Larval Crustacean Nutrition: A Review. Rev. Fish. Sci. 6(1,2): 55-68. 
Sorgeloos, P. 1997. Report on the resource assessment of Urmiah Lake Artemia cysts and biomass. Belgium, Ghent University.

Stephens, D. \& Birdsey, P. 2002. Population dynamics of the brine shrimp, Artemia franciscana, in Great Salt Lake and regulation of commercial shrimp harvest. In: Gwynn, J.W. (ed.) An overview of change. Utah Geological Survey, Natural Resources, special publication, USA. 327-336pp.

Van Stappen, G., Fayazi, G. \& Sorgeloos, P. 2001. International study on Artemia LXIII. Field study of the Artemia urmiana (Günther, 1890) population in Lake Urmiah, Iran. Hydrobiologia 466: 133-143.

Wurtsbaugh, W.A., \& Gliwicz, Z. M. 2001. Limnological control of brine shrimp population dynamics and cyst production in the Great Salt Lake Utah. Hydrobiologia 466: 119-132. 